Published in final edited form as:

Methods Mol Biol. 2012 ; 822: 295-306. doi:10.1007/978-1-61779-427-8_21.

\title{
miRNAs in Human Cancer
}

\author{
Xiaomin Zhong, George Coukos, and Lin Zhang
}

\begin{abstract}
MicroRNAs (miRNAs) are small ( 18-25 nucleotides), endogenous, noncoding RNAs that regulate gene expression in a sequence-specific manner via the degradation of target mRNAs or the inhibition of protein translation. miRNAs are predicted to target up to one-third of all human mRNAs. Each miRNA can target hundreds of transcripts and proteins directly or indirectly, and more than one miRNA can converge on a single target transcript; thus, the potential regulatory circuitry afforded by miRNAs is enormous. Increasing evidence is revealing that the expression of miRNAs is deregulated in cancer. High-throughput miRNA quantification technologies provide powerful tools to study global miRNA profiles. It has become progressively more apparent that, although the number of miRNAs $(\sim 1,000)$ is much smaller than the number of protein-coding genes $(\sim 22,000)$, miRNA expression signatures more accurately reflect the developmental lineage and tissue origin of human cancers. Large-scale studies in human cancer have further demonstrated that miRNA expression signatures are associated not only with specific tumor subtypes but also with clinical outcomes.
\end{abstract}

\section{Keywords}

MicroRNA; Noncoding RNA; Cancer

\section{Introduction}

Cancer is a disease involving multistep changes in the genome (1). Recent studies have focused mainly on protein-coding genes, and little is known about the alterations of functional noncoding sequences in cancer (2-4). MicroRNAs (miRNAs) are small ( 18-25 nucleotide), endogenous, noncoding RNAs that regulate gene expression in a sequencespecific manner (5-8). Rapidly accumulating evidence indicates that miRNAs are involved in the initiation and progression of cancer in several ways. First, miRNAs act as key regulators of various fundamental biological processes that share common pathways with cancer, such as development, differentiation, apoptosis, and cell proliferation (5-7). Second, increasing evidence shows that the expression of miRNAs is markedly deregulated in cancer due to multiple genomic and epigenetic alterations (2, 9-22), and third, several miRNAs have been shown to serve as tumor suppressor genes or oncogenes $(3,12,19,20,23-34)$. The investigation of miRNAs in cancer may provide novel strategies for both the diagnosis and treatment of this disease.

\section{Biogenesis of miRNAs}

With the exception of those from the Alu repeat regions, which are transcribed by RNA polymerase III (Pol III) (35), most miRNA genes are derived from primary miRNA 
transcripts (pri-miRNAs) which are produced by Pol II and contain a $5^{\prime}$ cap and a poly(A) tail $(36,37)$. The pri-miRNA is cleaved within the nucleus by a multiprotein complex called Microprocessor, which is composed of the RNase III enzyme Drosha and the doublestranded RNA-binding domain (dsRBD) protein DGCR8/Pasha (38-42), into a 70-nt hairpin precursor known as pre-miRNA. Next, the pre-miRNA is exported into the cytoplasm by Exportin-5 via a Ran-GTP-dependent mechanism (43-45). The pre-miRNA is further cleaved into a mature 22 -nt miRNA:miRNA* duplex by an RNase III enzyme, Dicer, in association with its partners, TRBP/Loquacious and PACT in human cells $(46,47)$. Subsequently, an RNA-induced silencing complex called RISC is assembled with the protein Argonaute (Ago) $2(48,49)$. The miRNA strand is selectively incorporated into the RISC complex $(50,51)$ and guides the complex specifically to its mRNA targets through base-pairing interactions (Fig. 1).

\section{3. miRNA Silencing Mechanisms}

miRNAs can downregulate the expression of their target genes via two different mechanisms; the mechanism used depends on the complementarity between the miRNA and its target. miRNAs with perfect or near-perfect complementarity to the target sequence induce the cleavage and degradation of the transcript by initiating deadenylation and decapping of the mRNA (52). However, most miRNAs bind imperfectly to their target sequences and function by repressing protein translation. The underlying molecular mechanisms resulting in this repression have been studied intensively using in vitro cell-free systems (53). Recently, Wakiyama et al. established a cell-free system derived from human embryonic kidney (HEK) 293 cells and demonstrated that efficient miRNA-guided translational repression requires a $\mathrm{m}^{7} \mathrm{G}$-cap as well as a poly(A) tail (54); this is consistent with a previous report using a rabbit reticulocyte lysate system (55). In addition, a study utilizing extracts from mouse Krebs-2 ascites cells (56) showed that inhibition of translation initiation can be due to changes in ribosome recruitment to the mRNA as well as targeting of the mRNA cap structure. The dilemma of how the miRNA ribonucleoprotein complex (miRNPs) that is bound to the $3^{\prime}$ UTR of a target mRNA interferes with the initiation of translation was resolved by Kiriakidou et al. (57). They identified a motif (MC) within the Mid domain of Ago proteins, which bears significant similarity to the $\mathrm{m}^{7} \mathrm{G}$ cap-binding domain of eIF4E, an essential translation initiation factor. In their model, the Ago proteins compete with the eIF4E for cap binding and thus repress the initiation of translation. Inhibition of translation initiation by mir-2 was similarly observed in a cell-free system from Drosophila embryos. Interestingly, mir-2 induced the formation of structures (heavier than 80S) known as "pseudo-polysomes," which resemble cytoplasmic processing bodies (P bodies) (58).

\section{Oncomirs in Cancer}

Changes in miRNA expression and function may contribute to the initiation and maintenance of tumors. Such miRNAs have been referred to as "oncomirs," and they may serve as both tumor suppressors and oncogenes (3). The first indication of miRNAs as tumor suppressors came from a report by Calin et al. where they found that patients diagnosed with B-cell chronic lymphocytic leukemia (B-CLL) have frequent deletions or downregulation of 
the mir-15a and mir-16-1 genes on chromosome 13q14.3 (23). A follow-up study demonstrated that mir-15a and mir-16-1 negatively regulate the antiapoptotic protein BCL2 at a posttranscriptional level (59), and their function in leukaemogenesis and lymphomagenesis has been supported by additional studies $(9,10,60)$. Some other miRNAs have also been shown to function as tumor suppressor genes, for example, the let-7 family, which are negative regulators of RAS (26). Other miRNAs can function as oncogenes. The mir-17-92 cluster was found by He et al. (25) to be upregulated in $65 \%$ of B-cell lymphomas, and its overexpression accelerated the development of malignant lymphomas in a transplantation mouse model. Upregulation of mir-21 has been reported in glioblastomas (24) and breast cancer (61), where it exerts an antiapoptotic function. mir-155 is remarkably overexpressed and linked to tumorigenesis (likely in cooperation with MYC) in pediatric Burkitt, Hodgkin, primary mediastinal, and diffuse large-B-cell lymphomas (62-65) as well as in breast cancer (61). In addition, mir-372 and mir-373 have been implicated as oncogenes in testicular germ cell tumors (28).

\section{Deregulation of miRNAs in Cancer}

The underlying mechanisms of miRNA deregulation in human cancer are not well understood, however, recent findings indicate that multiple processes are involved (21). It has been well documented that most primary miRNAs are transcribed from Pol II promoters that are regulated by transcription factors $(5-8,36,37)$, and several examples of miRNA deregulation in cancer due to transcriptional deregulation have been reported $(27,29,66-$ 68). Recent studies also suggest that epigenetic alterations play a critical role in deregulating miRNA expression in human cancers $(12,21,69)$, and that mutations may contribute to the downregulation of mature miRNAs (10). Over $50 \%$ of miRNAs are aligned to genomic fragile sites or regions associated with cancers (13), and several groups have provided evidence that DNA copy number abnormalities are involved in miRNA deregulation $(14,23$, 25). Finally, the key proteins in the miRNA biogenesis pathway may be dysfunctional (70) or deregulated in cancer (71-74), thereby enhancing tumorigenesis (75). Thus, transcriptional deregulation, epigenetic alterations, mutations, DNA copy number abnormalities, and defects in the miRNA biogenesis machinery might contribute either alone, but more likely together, to the deregulation of miRNAs in human cancer.

Global expression of miRNAs is seemingly deregulated in most cancer types, according to reports from recent high-throughput studies $(2,9-11,21,76,77)$. Interestingly, some studies suggest that miRNA expression may be widely downregulated in human tumors relative to normal tissues, as revealed by bead-based flow cytometry (9) and miRNA microarrays (21). However, other microarray studies have reported a tumor-specific pattern of down- and upregulation of miRNA genes $(10,11,76)$. The selection of control samples may therefore be critical in the interpretation of these results. For example, normal ovaries are composed mainly of stroma, with smaller amounts of surface epithelium, thus the whole ovary may not serve as an optimal control for epithelial ovarian cancer studies (78). Recently, miRNA profiles in ovarian cancer were reported by several independent groups, using different control samples $(17,20,21,79)$. Although the overall conclusion of these studies is consistent, i.e., the expression of miRNAs is highly deregulated in ovarian cancer, the 
detailed expression patterns of each study are distinct, highlighting the challenge of determining an appropriate control tissue sample for profiling studies.

Transcriptional regulation is one of the key steps controlling the expression of miRNA, and several studies have demonstrated that miRNA deregulation in cancer can be due to changes in miRNA transcription. The expression of several miRNAs, including the oncogenic miRNA mir-17-92 cluster, is regulated by the transcriptional factor c-Myc $(27,66)$. It has been shown that $c-M y c$ is amplified and overexpressed in several types of human tumors, which suggests that this may contribute to the upregulation of mir-17-92 in cancer $(27,66)$. In addition, the miRNA tumor suppressor mir-34 is regulated by the transcription factor p53 $(29,80-84)$, and p53 inactivation is believed to decrease mir-34 expression in human cancers (85). Finally, activation of the transcriptional factor HIF may be important to the upregulation of mir-210 expression in human cancer $(67,68,86)$. Taken together, an increasing amount of evidence indicates that transcriptional deregulation plays an important role in the deregulation of miRNAs in human cancer.

Epigenetic changes such as DNA methylation and histone modification play an important role in chromatin remodeling and in the general regulation of protein-coding gene expression in human cancer (87). Likewise, such mechanisms may also function to affect miRNA expression in cancer. To test this hypothesis, several groups treated cancer cell lines with DNA-demethylating reagents and/or histone deacetylase inhibitors in vitro and monitored miRNA expression by microarray analysis $(12,76,88,89)$. The results suggest that epigenetic alterations may play a critical role in regulating miRNA expression in human cancers, and therefore epigenetic treatments may provide novel strategies for cancer therapy.

Alterations in DNA copy number is one mechanism that can modify gene expression and function, and DNA dosage alterations in somatic cells are frequent contributors to cancer (90). The first example of a miRNA gene with an alteration in DNA copy number in cancer was reported in CLL patients. The genes mir-16-1 and mir-15a on chromosome 13q14 were deleted in more than $50 \%$ of the CLL patients studied, with concurrent reduced expression in $\sim 65 \%$ patients (23). Additional studies demonstrated that these two miRNAs suppress $B C L 2$ expression and may serve as tumor suppressor genes in this disease (59). Deletions of mir-16-1 and mir-15a were later identified in epithelial tumors, such as pituitary adenomas (91), and in ovarian and breast cancers (14). In 2004, the amplification of C13orf25 on chromosome 13q31-32 was first reported in lymphoma patients (92). Interestingly, this amplified region contains seven miRNAs as a polycistronic cluster, and there was an increased expression of primary and mature miRNAs derived from this locus in this type of lymphoma $(25,93)$. We now know that this miRNA cluster actually serves as an oncogene in human cancer $(25,94,95)$ by altering the balance between cell death and proliferation via a $c-M y c$ mediated pathway $(27,95)$. Using a bioinformatics based approach on data obtained from public databases, Calin et al. (13) compared 186 miRNA loci to the sequences of previously reported nonrandom genetic alterations and found that miRNA genes frequently reside in fragile sites, as well as in minimal regions of loss of heterozygosity, minimal regions of amplification, and common breakpoint regions. Recently, this finding was experimentally confirmed in an array-based comparative genomic hybridization (aCGH) study in 227 human tumors (14). A more recent study has suggested that a loss in genomic 
copy number may account for the downregulation of approximately $15 \%$ of miRNAs in advanced ovarian tumors (21). These findings support the notion that alterations in the DNA copy number of miRNA genes are highly prevalent in cancer and may account in part for miRNA gene deregulation.

\section{6. miRNA-Based Cancer Therapy}

The binding of miRNAs to their targets are governed by the rules of Watson-Crick base pairing. Therefore, an obvious molecule that could be used to inhibit an miRNA is an antimiRNA oligonucleotide (AMO), which competitively blocks the interaction between the miRNA and its target (96). AMOs can be chemically modified in a variety of ways to improve their stability. One example is a locked nucleic acid (LNA), often referred to as inaccessible RNAs, which is a bicyclic high-affinity RNA analogue where the ribose moiety is chemically locked in an RNA-mimicking $\mathrm{N}$-type ( $\mathrm{C}^{\prime}$-endo) conformation by the introduction of an extra $2^{\prime}-\mathrm{O}, 4^{\prime}-\mathrm{C}$ methylene bridge (97). The locked ribose conformation enhances base stacking and backbone pre-organization and significantly increases the thermal stability upon hybridization with complementary single-stranded RNA target molecules. In addition, LNAs are compatible with RNase H cleavage and display high aqueous solubility and low toxicity in vivo (98). Other oligonucleotide analogues, such as morpholinos (99), 2'-O-methyl-(100), and 2'-O-methoxyethyl-modified (2'-MOE) oligonucleotides (101) have also been shown to be efficient in functionally inhibiting miRNAs. Besides chemical modifications, some improvements in inhibitor potency have been observed by increasing the length of the AMOs (102). Optimized secondary structural elements that flank the antisense core have also been shown to be highly potent and specifically block RISC activity in vitro for extended periods of time, thus suggesting structures surrounding or adjacent to the antisense core sequence are major determinants of inhibitor potency (103). In summary, a combination of optimization of sequences, structures, and/or chemical modifications may be required to produce a potent AMO.

Since protein-coding tumor suppressor genes can inhibit tumor growth, it has been proposed that restoring tumor suppressive miRNAs may also have an antitumorigenic effect. An example of miRNA replacement therapy is with mir-15 and mir-16, which target BCL2 (10) and are often deleted in CLL patients (23). It has been reported that the transfection of mir-15/16 expressing constructs resulted in the reduction of BCL2 protein levels and increased apoptosis in cancer cell lines. This study highlights the possibility of treating tumors displaying BCL2 overexpression by restoring mir-15a and mir-16-1 expression. Another therapeutic candidate is mir-124a, whose expression is downregulated in acute lymphoblastic leukemia (ALL) due to hypermethylation of the promoter as well as histone modifications, resulting in an upregulation of the expression of target genes, including CDK6, and the phosphorylation of retinoblastoma (Rb). Accordingly, forced expression of pre-mir-124a led to decreased tumorigenicity in a xenogeneic mouse model of ALL (104). Mendell et al. have recently demonstrated that mir-26a in hepatocellular carcinoma (HCC) represents an additional example of a tumor suppressing miRNA, and that systemic administration of this miRNA using adeno-associated virus (AAV) in an animal model of HCC results in inhibition of cancer cell proliferation, induction of tumor-specific apoptosis, and significant protection from disease progression without toxicity (105). 


\section{Acknowledgments}

This work was supported in part by grants from the Breast Cancer Alliance, the Ovarian Cancer Research Fund (Liz Tilberis Scholar), the Mary Kay Ash Charitable Foundation, the National Cancer Institute (R01CA142776 and Ovarian Cancer SPORE P50-CA83638-7951 project 3), and the US Department of Defense (W81XWH-10-1-0082).

\section{References}

1. Hanahan D, Weinberg RA. The hallmarks of cancer. Cell. 2000; 100:57-70. [PubMed: 10647931]

2. Calin GA, Croce CM. MicroRNA signatures in human cancers. Nat Rev Cancer. 2006; 6:857-66. [PubMed: 17060945]

3. Esquela-Kerscher A, Slack FJ. Oncomirs - microRNAs with a role in cancer. Nat Rev Cancer. 2006; 6:259-69. [PubMed: 16557279]

4. Calin GA, Liu CG, Ferracin M, Hyslop T, Spizzo R, Sevignani C, et al. Ultraconserved regions encoding ncRNAs are altered in human leukemias and carcinomas. Cancer Cell. 2007; 12:215-29. [PubMed: 17785203]

5. Bartel DP. MicroRNAs: genomics, biogenesis, mechanism, and function. Cell. 2004; 116:281-97. [PubMed: 14744438]

6. Ambros V. The functions of animal microRNAs. Nature. 2004; 431:350-355. [PubMed: 15372042]

7. He L, Hannon GJ. MicroRNAs: small RNAs with a big role in gene regulation. Nat Rev Genet. 2004; 5:522-31. [PubMed: 15211354]

8. Zamore PD, Haley B. Ribo-gnome: the big world of small RNAs. Science. 2005; 309:1519-24. [PubMed: 16141061]

9. Lu J, Getz G, Miska EA, Alvarez-Saavedra E, Lamb J, Peck D, et al. MicroRNA expression profiles classify human cancers. Nature. 2005; 435:834-8. [PubMed: 15944708]

10. Calin GA, Ferracin M, Cimmino A, Di Leva G, Shimizu M, Wojcik SE, et al. A MicroRNA signature associated with prognosis and progression in chronic lymphocytic leukemia. N Engl J Med. 2005; 353:1793-801. [PubMed: 16251535]

11. Volinia S, Calin GA, Liu CG, Ambs S, Cimmino A, Petrocca F, et al. A microRNA expression signature of human solid tumors defines cancer gene targets. Proc Natl Acad Sci USA. 2006; 103:2257-61. [PubMed: 16461460]

12. Saito Y, Liang G, Egger G, Friedman JM, Chuang JC, Coetzee GA, et al. Specific activation of microRNA-127 with downregulation of the proto-oncogene BCL6 by chromatin-modifying drugs in human cancer cells. Cancer Cell. 2006; 9:435-43. [PubMed: 16766263]

13. Calin GA, Sevignani C, Dumitru CD, Hyslop T, Noch E, Yendamuri S, et al. Human microRNA genes are frequently located at fragile sites and genomic regions involved in cancers. Proc Natl Acad Sci USA. 2004; 101:2999-3004. [PubMed: 14973191]

14. Zhang L, Huang J, Yang N, Greshock J, Megraw MS, Giannakakis A, et al. microRNAs exhibit high frequency genomic alterations in human cancer. Proc Natl Acad Sci USA. 2006; 103:913641. [PubMed: 16754881]

15. Fazi F, Racanicchi S, Zardo G, Starnes LM, Mancini M, Travaglini L, et al. Epigenetic silencing of the myelopoiesis regulator microRNA-223 by the AML1/ETO oncoprotein. Cancer Cell. 2007; 12:457-66. [PubMed: 17996649]

16. Sevignani C, Calin GA, Nnadi SC, Shimizu M, Davuluri RV, Hyslop T, et al. MicroRNA genes are frequently located near mouse cancer susceptibility loci. Proc Natl Acad Sci USA. 2007; 104:8017-22. [PubMed: 17470785]

17. Iorio MV, Visone R, Di Leva G, Donati V, Petrocca F, Casalini P, et al. MicroRNA signatures in human ovarian cancer. Cancer Res. 2007; 67:8699-707. [PubMed: 17875710]

18. Lu L, Katsaros D, de la Longrais IA, Sochirca O, Yu H. Hypermethylation of let-7a-3 in epithelial ovarian cancer is associated with low insulin-like growth factor-II expression and favorable prognosis. Cancer Res. 2007; 67:10117-22. [PubMed: 17974952] 
19. Shell S, Park SM, Radjabi AR, Schickel R, Kistner EO, Jewell DA, et al. Let-7 expression defines two differentiation stages of cancer. Proc Natl Acad Sci USA. 2007; 104:11400-5. [PubMed: 17600087]

20. Yang H, Kong W, He L, Zhao JJ, O’Donnell JD, Wang J, et al. MicroRNA expression profiling in human ovarian cancer: miR-214 induces cell survival and cisplatin resistance by targeting PTEN. Cancer Res. 2008; 68:425-33. [PubMed: 18199536]

21. Zhang L, Volinia S, Bonome T, Calin GA, Greshock J, Yang N, et al. Genomic and epigenetic alterations deregulate microRNA expression in human epithelial ovarian cancer. Proc Natl Acad Sci USA. 2008; 105:7004-9. [PubMed: 18458333]

22. Yang N, Kaur S, Volinia S, Greshock J, Lassus H, Hasegawa K, et al. MicroRNA microarray identifies Let-7i as a novel biomarker and therapeutic target in human epithelial ovarian cancer. Cancer Res. 2008; 68:10307-14. [PubMed: 19074899]

23. Calin GA, Dumitru CD, Shimizu M, Bichi R, Zupo S, Noch E, et al. Frequent deletions and downregulation of micro-RNA genes miR15 and miR16 at 13q14 in chronic lymphocytic leukemia. Proc Natl Acad Sci USA. 2002; 99:15524-9. [PubMed: 12434020]

24. Chan JA, Krichevsky AM, Kosik KS. MicroRNA-21 is an antiapoptotic factor in human glioblastoma cells. Cancer Res. 2005; 65:6029-33. [PubMed: 16024602]

25. He L, Thomson JM, Hemann MT, Hernando-Monge E, Mu D, et al. A microRNA polycistron as a potential human oncogene. Nature. 2005; 435:828-33. [PubMed: 15944707]

26. Johnson SM, Grosshans H, Shingara J, Byrom M, Jarvis R, Cheng A, et al. RAS is regulated by the let-7 microRNA family. Cell. 2005; 120:635-47. [PubMed: 15766527]

27. O’Donnell KA, Wentzel EA, Zeller KI, Dang CV, Mendell JT. c-Myc-regulated microRNAs modulate E2F1 expression. Nature. 2005; 435:839-43. [PubMed: 15944709]

28. Voorhoeve PM, le Sage C, Schrier M, Gillis AJ, Stoop H, Nagel R, et al. A genetic screen implicates miRNA-372 and miRNA-373 as oncogenes in testicular germ cell tumors. Cell. 2006; 124:1169-81. [PubMed: 16564011]

29. He L, He X, Lim LP, de Stanchina E, Xuan Z, Liang Y, et al. A microRNA component of the p53 tumour suppressor network. Nature. 2007; 447:1130-4. [PubMed: 17554337]

30. Mayr C, Hemann MT, Bartel DP. Disrupting the pairing between let-7 and Hmga2 enhances oncogenic transformation. Science. 2007; 315:1576-9. [PubMed: 17322030]

31. Corney DC, Flesken-Nikitin A, Godwin AK, Wang W, Nikitin AY. MicroRNA-34b and MicroRNA-34c are targets of p53 and cooperate in control of cell proliferation and adhesionindependent growth. Cancer Res. 2007; 67:8433-8. [PubMed: 17823410]

32. Ma L, Teruya-Feldstein J, Weinberg RA. Tumour invasion and metastasis initiated by microRNA-10b in breast cancer. Nature. 2007; 449:682-8. [PubMed: 17898713]

33. Tavazoie SF, Alarcon C, Oskarsson T, Padua D, Wang Q, Bos PD, et al. Endogenous human microRNAs that suppress breast cancer metastasis. Nature. 2008; 451:147-52. [PubMed: 18185580]

34. Varambally S, Cao Q, Mani RS, Shankar S, Wang X, Ateeq B, et al. Genomic loss of microRNA-101 leads to overexpression of histone methyltransferase EZH2 in cancer. Science. 2008; 322:1695-9. [PubMed: 19008416]

35. Borchert GM, Lanier W, Davidson BL. RNA polymerase III transcribes human microRNAs. Nat Struct Mol Biol. 2006; 13:1097-101. [PubMed: 17099701]

36. Lee Y, Kim M, Han J, Yeom KH, Lee S, Baek SH, et al. MicroRNA genes are transcribed by RNA polymerase II. EMBO J. 2004; 23:4051-60. [PubMed: 15372072]

37. Cai X, Hagedorn $\mathrm{CH}$, Cullen BR. Human microRNAs are processed from capped, polyadenylated transcripts that can also function as mRNAs. RNA. 2004; 10:1957-66. [PubMed: 15525708]

38. Denli AM, Tops BB, Plasterk RH, Ketting RF, Hannon GJ. Processing of primary microRNAs by the Microprocessor complex. Nature. 2004; 432:231-5. [PubMed: 15531879]

39. Gregory RI, Yan KP, Amuthan G, Chendrimada T, Doratotaj B, Cooch N, et al. The Microprocessor complex mediates the genesis of microRNAs. Nature. 2004; 432:235-40. [PubMed: 15531877] 
40. Curiel TJ, Coukos G, Zou L, Alvarez X, Cheng P, Mottram P, et al. Specific recruitment of regulatory $\mathrm{T}$ cells in ovarian carcinoma fosters immune privilege and predicts reduced survival. Nat Med. 2004; 10:942-9. [PubMed: 15322536]

41. Landthaler M, Yalcin A, Tuschl T. The human DiGeorge syndrome critical region gene 8 and Its D. melanogaster homolog are required for miRNA biogenesis. Curr Biol. 2004; 14:2162-7. [PubMed: 15589161]

42. Lee Y, Ahn C, Han J, Choi H, Kim J, Yim J, et al. The nuclear RNase III Drosha initiates microRNA processing. Nature. 2003; 425:415-9. [PubMed: 14508493]

43. Yi R, Qin Y, Macara IG, Cullen BR. Exportin-5 mediates the nuclear export of pre-microRNAs and short hairpin RNAs. Genes Dev. 2003; 17:3011-6. [PubMed: 14681208]

44. Lund E, Guttinger S, Calado A, Dahlberg JE, Kutay U. Nuclear export of microRNA precursors. Science. 2004; 303:95-8. [PubMed: 14631048]

45. Bohnsack MT, Czaplinski K, Gorlich D. Exportin 5 is a RanGTP-dependent dsRNA-binding protein that mediates nuclear export of pre-miRNAs. RNA. 2004; 10:185-91. [PubMed: 14730017]

46. Hutvagner G, McLachlan J, Pasquinelli AE, Balint E, Tuschl T, Zamore PD. A cellular function for the RNA-interference enzyme Dicer in the maturation of the let-7 small temporal RNA. Science. 2001; 293:834-8. [PubMed: 11452083]

47. Ketting RF, Fischer SE, Bernstein E, Sijen T, Hannon GJ, Plasterk RH. Dicer functions in RNA interference and in synthesis of small RNA involved in developmental timing in C. elegans. Genes Dev. 2001; 15:2654-9. [PubMed: 11641272]

48. Gregory RI, Chendrimada TP, Cooch N, Shiekhattar R. Human RISC couples microRNA biogenesis and posttranscriptional gene silencing. Cell. 2005; 123:631-40. [PubMed: 16271387]

49. Maniataki E, Mourelatos Z. A human, ATP-independent, RISC assembly machine fueled by premiRNA. Genes Dev. 2005; 19:2979-90. [PubMed: 16357216]

50. Schwarz DS, Hutvagner G, Du T, Xu Z, Aronin N, Zamore PD. Asymmetry in the assembly of the RNAi enzyme complex. Cell. 2003; 115:199-208. [PubMed: 14567917]

51. Du T, Zamore PD. microPrimer: the biogenesis and function of microRNA. Development. 2005; 132:4645-52. [PubMed: 16224044]

52. Pillai RS, Bhattacharyya SN, Filipowicz W. Repression of protein synthesis by miRNAs: how many mechanisms? Trends Cell Biol. 2007; 17:118-26. [PubMed: 17197185]

53. Standart N, Jackson RJ. MicroRNAs repress translation of $m 7 \mathrm{Gppp}$-capped target mRNAs in vitro by inhibiting initiation and promoting deadenylation. Genes Dev. 2007; 21:1975-82. [PubMed: 17699746]

54. Wakiyama M, Takimoto K, Ohara O, Yokoyama S. Let-7 microRNA-mediated mRNA deadenylation and translational repression in a mammalian cell-free system. Genes Dev. 2007; 21:1857-62. [PubMed: 17671087]

55. Wang B, Love TM, Call ME, Doench JG, Novina CD. Recapitulation of short RNA-directed translational gene silencing in vitro. Mol Cell. 2006; 22:553-60. [PubMed: 16713585]

56. Mathonnet G, Fabian MR, Svitkin YV, Parsyan A, Huck L, Murata T, et al. MicroRNA inhibition of translation initiation in vitro by targeting the cap-binding complex eIF4F. Science. 2007; 317:1764-7. [PubMed: 17656684]

57. Kiriakidou M, Tan GS, Lamprinaki S, De Planell-Saguer M, Nelson PT, Mourelatos Z. An mRNA m7G cap binding-like motif within human Ago2 represses translation. Cell. 2007; 129:1141-51. [PubMed: 17524464]

58. Thermann R, Hentze MW. Drosophila miR2 induces pseudo-polysomes and inhibits translation initiation. Nature. 2007; 447:875-8. [PubMed: 17507927]

59. Cimmino A, Calin GA, Fabbri M, Iorio MV, Ferracin M, Shimizu M, et al. miR-15 and miR-16 induce apoptosis by targeting BCL2. Proc Natl Acad Sci USA. 2005; 102:13944-9. [PubMed: 16166262]

60. Michael MZ, SM OC, van Holst Pellekaan NG, Young GP, James RJ. Reduced accumulation of specific microRNAs in colorectal neoplasia. Mol Cancer Res. 2003; 1:882-91. [PubMed: 14573789] 
61. Iorio MV, Ferracin M, Liu CG, Veronese A, Spizzo R, Sabbioni S, et al. MicroRNA gene expression deregulation in human breast cancer. Cancer Res. 2005; 65:7065-70. [PubMed: 16103053]

62. van den Berg A, Kroesen BJ, Kooistra K, de Jong D, Briggs J, Blokzijl T, et al. High expression of B-cell receptor inducible gene BIC in all subtypes of Hodgkin lymphoma. Genes Chromosomes Cancer. 2003; 37:20-8. [PubMed: 12661002]

63. Metzler M, Wilda M, Busch K, Viehmann S, Borkhardt A. High expression of precursor microRNA-155/BIC RNA in children with Burkitt lymphoma. Genes Chromosomes Cancer. 2004; 39:167-9. [PubMed: 14695998]

64. Kluiver J, Poppema S, de Jong D, Blokzij1 T, Harms G, Jacobs S, et al. BIC and miR-155 are highly expressed in Hodgkin, primary mediastinal and diffuse large B cell lymphomas. J Pathol. 2005; 207:243-9. [PubMed: 16041695]

65. Eis PS, Tam W, Sun L, Chadburn A, Li Z, Gomez MF, et al. Accumulation of miR-155 and BIC RNA in human B cell lymphomas. Proc Natl Acad Sci USA. 2005; 102:3627-32. [PubMed: 15738415]

66. Chang TC, Yu D, Lee YS, Wentzel EA, Arking DE, West KM, et al. Widespread microRNA repression by Myc contributes to tumorigenesis. Nat Genet. 2008; 40:43-50. [PubMed: 18066065]

67. Giannakakis A, Sandaltzopoulos R, Greshock J, Liang S, Huang J, Hasegawa K, et al. miR-210 links hypoxia with cell cycle regulation and is deleted in human epithelial ovarian cancer. Cancer Biol Ther. 2007; 7

68. Kulshreshtha R, Ferracin M, Wojcik SE, Garzon R, Alder H, Agosto-Perez FJ, et al. A microRNA signature of hypoxia. Mol Cell Biol. 2007; 27:1859-67. [PubMed: 17194750]

69. Yang N, Coukos G, Zhang L. MicroRNA epigenetic alterations in human cancer: one step forward in diagnosis and treatment. Int J Cancer. 2008; 122:963-8. [PubMed: 18098137]

70. Thomson JM, Newman M, Parker JS, Morin-Kensicki EM, Wright T, Hammond SM. Extensive post-transcriptional regulation of microRNAs and its implications for cancer. Genes Dev. 2006; 20:2202-7. [PubMed: 16882971]

71. Muralidhar B, Goldstein LD, Ng G, Winder DM, Palmer RD, Gooding EL, et al. Global microRNA profiles in cervical squamous cell carcinoma depend on Drosha expression levels. J Pathol. 2007; 212:368-77. [PubMed: 17471471]

72. Chiosea S, Jelezcova E, Chandran U, Luo J, Mantha G, Sobol RW, et al. Overexpression of Dicer in precursor lesions of lung adenocarcinoma. Cancer Res. 2007; 67:2345-50. [PubMed: 17332367]

73. Chiosea S, Jelezcova E, Chandran U, Acquafondata M, McHale T, Sobol RW, et al. Up-regulation of dicer, a component of the MicroRNA machinery, in prostate adenocarcinoma. Am J Pathol. 2006; 169:1812-20. [PubMed: 17071602]

74. Karube Y, Tanaka H, Osada H, Tomida S, Tatematsu Y, Yanagisawa K, et al. Reduced expression of Dicer associated with poor prognosis in lung cancer patients. Cancer Sci. 2005; 96:111-5. [PubMed: 15723655]

75. Kumar MS, Lu J, Mercer KL, Golub TR, Jacks T. Impaired microRNA processing enhances cellular transformation and tumorigenesis. Nat Genet. 2007; 39:673-7. [PubMed: 17401365]

76. Yanaihara N, Caplen N, Bowman E, Seike M, Kumamoto K, Yi M, et al. Unique microRNA molecular profiles in lung cancer diagnosis and prognosis. Cancer Cell. 2006; 9:189-98. [PubMed: 16530703]

77. Cummins JM, He Y, Leary RJ, Pagliarini R, Diaz LA Jr. Sjoblom T, et al. The colorectal microRNAome. Proc Natl Acad Sci USA. 2006; 103:3687-92. [PubMed: 16505370]

78. Zorn KK, Jazaeri AA, Awtrey CS, Gardner GJ, Mok SC, Boyd J, et al. Choice of normal ovarian control influences determination of differentially expressed genes in ovarian cancer expression profiling studies. Clin Cancer Res. 2003; 9:4811-8. [PubMed: 14581352]

79. Nam EJ, Yoon H, Kim SW, Kim H, Kim YT, Kim JH, et al. MicroRNA Expression Profiles in Serous Ovarian Carcinoma. Clin Cancer Res. 2008; 14:2690-5. [PubMed: 18451233]

80. Bommer GT, Gerin I, Feng Y, Kaczorowski AJ, Kuick R, Love RE, et al. p53-Mediated Activation of miRNA34 Candidate Tumor-Suppressor Genes. Curr Biol. 2007; 17:1298-307. [PubMed: 17656095] 
81. Chang TC, Wentzel EA, Kent OA, Ramachandran K, Mullendore M, Lee KH, et al. Transactivation of miR-34a by p53 broadly influences gene expression and promotes apoptosis. Mol Cell. 2007; 26:745-52. [PubMed: 17540599]

82. Raver-Shapira N, Marciano E, Meiri E, Spector Y, Rosenfeld N, Moskovits N, et al. Transcriptional activation of miR-34a contributes to p53-mediated apoptosis. Mol Cell. 2007; 26:731-43. [PubMed: 17540598]

83. Tarasov V, Jung P, Verdoodt B, Lodygin D, Epanchintsev A, Menssen A, et al. Differential regulation of microRNAs by $\mathrm{p} 53$ revealed by massively parallel sequencing: miR-34a is a 553 target that induces apoptosis and G1-arrest. Cell Cycle. 2007; 6:1586-93. [PubMed: 17554199]

84. Corney DC, Flesken-Nikitin A, Godwin AK, Wang W, Nikitin AY. MicroRNA-34b and MicroRNA-34c Are Targets of p53 and Cooperate in Control of Cell Proliferation and AdhesionIndependent Growth. Cancer Res. 2007; 67:8433-8. [PubMed: 17823410]

85. He L, He X, Lowe SW, Hannon GJ. microRNAs join the p53 network--another piece in the tumour-suppression puzzle. Nat Rev Cancer. 2007; 7:819-22. [PubMed: 17914404]

86. Camps C, Buffa FM, Colella S, Moore J, Sotiriou C, Sheldon H, et al. hsamiR-210 Is induced by hypoxia and is an independent prognostic factor in breast cancer. Clin Cancer Res. 2008; 14:13408. [PubMed: 18316553]

87. Egger G, Liang G, Aparicio A, Jones PA. Epigenetics in human disease and prospects for epigenetic therapy. Nature. 2004; 429:457-63. [PubMed: 15164071]

88. Scott GK, Mattie MD, Berger CE, Benz SC, Benz CC. Rapid alteration of microRNA levels by histone deacetylase inhibition. Cancer Res. 2006; 66:1277-81. [PubMed: 16452179]

89. Diederichs S, Haber DA. Sequence Variations of MicroRNAs in Human Cancer: Alterations in Predicted Secondary Structure Do Not Affect Processing. Cancer Res. 2006; 66:6097-104. [PubMed: 16778182]

90. Pinkel D, Albertson DG. Array comparative genomic hybridization and its applications in cancer. Nat Genet. 2005; 37(Suppl):S11-7. [PubMed: 15920524]

91. Bottoni A, Piccin D, Tagliati F, Luchin A, Zatelli MC, degli Uberti EC. miR-15a and miR-16-1 down-regulation in pituitary adenomas. J Cell Physiol. 2005; 204:280-5. [PubMed: 15648093]

92. Ota A, Tagawa H, Karnan S, Tsuzuki S, Karpas A, Kira S, et al. Identification and characterization of a novel gene, C13orf25, as a target for 13q31-q32 amplification in malignant lymphoma. Cancer Res. 2004; 64:3087-95. [PubMed: 15126345]

93. Tagawa H, Seto M. A microRNA cluster as a target of genomic amplification in malignant lymphoma. Leukemia. 2005; 19:2013-6. [PubMed: 16167061]

94. Hayashita Y, Osada H, Tatematsu Y, Yamada H, Yanagisawa K, Tomida S, et al. A polycistronic microRNA cluster, miR-17-92, is overexpressed in human lung cancers and enhances cell proliferation. Cancer Res. 2005; 65:9628-32. [PubMed: 16266980]

95. Dews M, Homayouni A, Yu D, Murphy D, Sevignani C, Wentzel E, et al. Augmentation of tumor angiogenesis by a Myc-activated microRNA cluster. Nat Genet. 2006; 38:1060-5. [PubMed: 16878133]

96. Weiler J, Hunziker J, Hall J. Anti-miRNA oligonucleotides (AMOs): ammunition to target miRNAs implicated in human disease? Gene Ther. 2006; 13:496-502. [PubMed: 16195701]

97. Vester B, Wengel J. LNA (locked nucleic acid): high-affinity targeting of complementary RNA and DNA. Biochemistry. 2004; 43:13233-41. [PubMed: 15491130]

98. Elmen J, Lindow M, Schutz S, Lawrence M, Petri A, Obad S, et al. LNA-mediated microRNA silencing in non-human primates. Nature. 2008; 452:896-9. [PubMed: 18368051]

99. Flynt AS, Li N, Thatcher EJ, Solnica-Krezel L, Patton JG. Zebrafish miR-214 modulates Hedgehog signaling to specify muscle cell fate. Nat Genet. 2007; 39:259-63. [PubMed: 17220889]

100. Krutzfeldt J, Rajewsky N, Braich R, Rajeev KG, Tuschl T, Manoharan M, et al. Silencing of microRNAs in vivo with 'antagomirs'. Nature. 2005; 438:685-9. [PubMed: 16258535]

101. Esau C, Davis S, Murray SF, Yu XX, Pandey SK, Pear M, et al. miR-122 regulation of lipid metabolism revealed by in vivo antisense targeting. Cell Metab. 2006; 3:87-98. [PubMed: 16459310] 
102. Hutvagner G, Simard MJ, Mello CC, Zamore PD. Sequence-specific inhibition of small RNA function. PLoS Biol. 2004; 2:E98. [PubMed: 15024405]

103. Vermeulen A, Robertson B, Dalby AB, Marshall WS, Karpilow J, Leake D, et al. Doublestranded regions are essential design components of potent inhibitors of RISC function. RNA. 2007; 13:723-30. [PubMed: 17400817]

104. Agirre X, Vilas-Zornoza A, Jimenez-Velasco A, Martin-Subero JI, Cordeu L, Garate L, et al. Epigenetic silencing of the tumor suppressor microRNA Hsa-miR-124a regulates CDK6 expression and confers a poor prognosis in acute lymphoblastic leukemia. Cancer Res. 2009; 69:4443-53. [PubMed: 19435910]

105. Kota J, Chivukula RR, O’Donnell KA, Wentzel EA, Montgomery CL, Hwang H-W, et al. Therapeutic microRNA Delivery Suppresses Tumorigenesis in a Murine Liver Cancer Model. Cell. 2009; 137:1005-17. [PubMed: 19524505] 


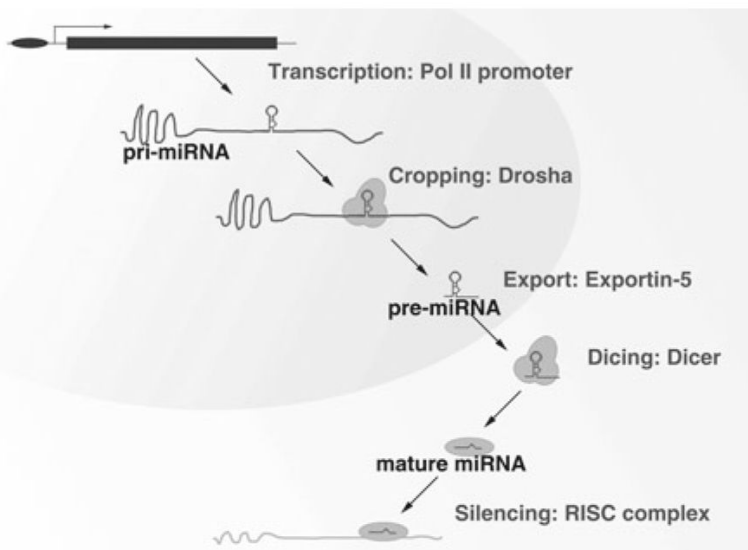

Fig. 1.

Biogenesis of miRNAs. miRNA genes are derived from primary miRNA transcripts which are produced by Pol II and contain a $5^{\prime}$ cap and a poly(A) tail. The pri-miRNA is cleaved within the nucleus by a multiprotein complex called Microprocessor into a $\sim 70$-nt hairpin precursor known as pre-miRNA. Next, the pre-miRNA is exported into the cytoplasm by Exportin-5. The pre-miRNA is further cleaved into a mature 22 -nt miRNA:miRNA* duplex by an RNase III enzyme, Dicer. Subsequently, an RNA-induced silencing complex called RISC is assembled with the protein Argonaute (Ago) 2. The miRNA strand is selectively incorporated into the RISC complex and guides the complex specifi cally to its mRNA targets through base-pairing interactions. 